\title{
Ioway Ethnohistory: A Review Part I
}

Duane Anderson

This article traces Ioway ethnohistory through three distinct periods. The first section deals with the emergence of the "Aiaoua" tribe from a portion of the prehistoric Oneota manifestation, located primarily in the state of Iowa. The second section deals with early historic accounts of the Ioway as they were reported in ten different locations in Iowa and Illinois prior to a series of land cessions that began in 1824 and ended with their departure to north-western Missouri by the Treaty of 1830. Part II of the article, which will appear in the next issue (Volume 42, Number 1), deals with the reservation period. After a treaty negotiated in 1836 with the U. S. government, the Iowa were found on a reserve in northwestern Kansas and southeastern Nebraska. Following additional land losses a portion of the tribe moved to Indian Territory where they were ultimately given another reservation which was ceded a few years later. The study concludes with the year 1929 when the Oklahoma Iowas' request for additional compensation for their ceded lands was favorably considered by the federal government.

ONEOTA TO AIAOUA (A.D. 950-1676)

In 1676 Members of the "Aiaoua" tribe visited Father Louis Andre at Green Bay, Wisconsin. The group, who was said to represent a large but poor tribe of Indians, provided for the first written record of what has come to be known as the Historic Ioway. ${ }^{1}$ The Ioway, known variously as "Ayooues,"

${ }^{1}$ Ruben Gold Thwaites (ed.), "Lower Canada, Illinois, Iroquois, Ottawas: 1675-1677," in Travels and Explorations of the Jesuit Missionaries in New France, 1610-1791 (Cleveland, The Burrows Brothers Co., 1900 ), Vol. 60, p. 203. 

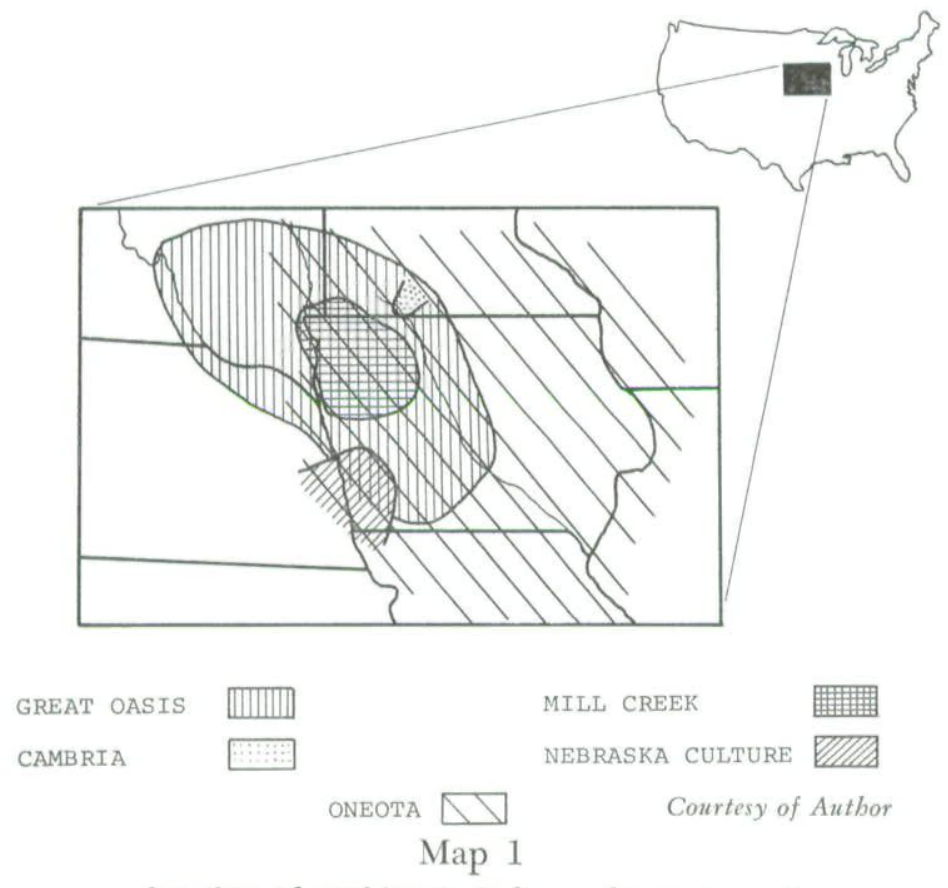

Location of prehistoric Indian cultures in and around the State of lowa at A.D. 1200.

"Ayoes," "Ayoa," "Hayuas," and "Aiouez" in the Historic Period, have been linked with a portion of the prehistoric Oneota manifestation in the state of Iowa by Mildred Mott, ${ }^{2} \mathrm{M}$. Wedel $^{3}$ and Dale Henning. ${ }^{4}$

The Oneota roots of the Ioway tribe are deep in the area of the Prairie Peninsula extending at least as far back as A.D. 950. At this time several distinctive cultural patterns were emerging: Great Oasis, Cambria, Mill Creek, Nebraska

${ }^{2}$ Mildred Mott, "The Relation of Historic Indian Tribes to Archaelogical Manifestations in Iowa," Iowa Journal of History and Politics, (Iowa City, 1938), Vol. 36, No. 3, pp. 227-314.

${ }^{3}$ Mildred Mott Wedel, "Oneota Sites on the Upper Iowa River," Missouri Archaeologist, (Columbia, 1959), Vol. 21, Nos. 2-4.

${ }^{4}$ Dale R. Henning, "Development and Interrelationships of Oneota Culture in the Lower Missouri River Valley," Missouri Archaeologist, (Columbia, 1970), Vol. 32, pp. 1-180. 
Culture (Glenwood phase) and Oneota (Map 1), but the only people who persisted into the Historic were the Oneota. The primary reason for this seems to lie in a slightly different adaptation to the environment on the part of the Oneota.

While other groups (particularly Mill Creek and Cambria) seem to have depended more heavily on horticulture and a settled way of life, the Oneota seem to have had a pattern of periodic movement coupled with a stronger emphasis on hunting and perhaps raiding (some Mill Creek sites are fortified). The general time period of A.D. 800-1250 featured climatic conditions amenable to both types of adaptations. This period, termed the Neo-Atlantic episode, ${ }^{5}$ was milder compared with the subsequent Pacific episode spanning A.D. 1250-1450. The more severe Pacific ${ }^{6}$ was due to an increase of zonal westerlies producing a desiccation of the horticultural environment. The Pacific episode saw a tightening of conditions throughout the prairies and the Central Plains, ${ }^{7}$ which is reflected in numerous culture-historical sequences. ${ }^{8}$

During the changes of the Pacific and early portions of the subsequent Neo-Boreal episodes, the Great Oasis, Nebraska, Cambria and Mill Creek manifestations disappear from the record. It seems likely that Oneota groups made adjustments in response to these changes and for the most part, they appear to have been successul ones.

Numerous sites of this group are found in a variety of ecological situations in seven different midwestern states along major streams and their tributaries. This broad prehistoric population provided for the emergence of a number of Siouan tribes including the Winnebago, Missouri, Osage, Little

${ }^{5}$ David A. Baerreis and Reid A. Bryson, "Climatic Episodes and the Dating of the Mississippian Cultures," Wisconsin Archaeologist, (Milwaukee, 1965), Vol. 46, No. 4, p. 215.

${ }^{6}$ Ibid., p. 213.

${ }^{7}$ Reid A. Bryson and David A. Baerreis, "Introduction and Project Summary," in Climatic Change and the Mill Creek Culture of Iowa, ed. by Dale R. Henning (Westfield, Journal of the Iowa Archaeological Society, 1968), Vol. 15, pp. 1-2.

${ }^{8}$ See for example Richard A. Krause, "Correlation of Phases in Central Plains Prehistory," in Two House Sites in the Central Plains: An Experiment in Archaeology, ed. by W. R. Wood (Topeka, Plains Anthropologist, 1969), Memoir 6, p. 89. 
Osage, Kansa, Oto and Ioway in the states of Wisconsin, Missouri, Kansas, Minnesota, Iowa, Nebraska and Illinois. ${ }^{9}$ These groups have been tied with greater or lesser success to resident Oneota populations (Map 2). The case for the Ioways is perhaps the best documented.

The earliest Oneota materials recorded to date come from Caracjou Point in Wisconsin (Wis 77: A.D. $890 \pm 80$ and M 786: A.D. $900 \pm 250$ ). The earliest Iowa material is found at the Dixon site in the northwestern part of the state (Wis 54: A.D. $930 \pm 80)$. The Iowa material is lumped by Henning ${ }^{10}$ with remains from the Blue Earth River of south central Minnesota as the Correctionville-Blue Earth phase. Also included

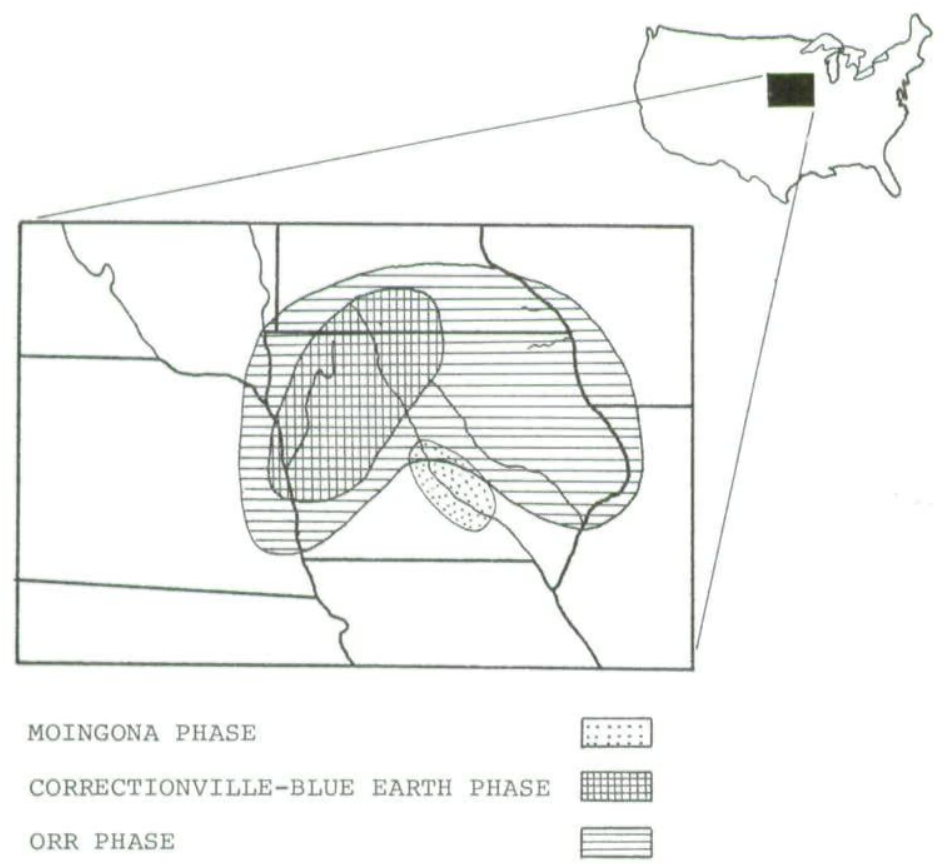

Map 2

Location of prehistoric and protohistoric Oneota phases thought to be related to the Historic loway.

${ }^{9}$ Henning, op. cit., pp. 168-70.

${ }^{10}$ Ibid., pp. 152-53. 
under this heading are materials from southeastern Nebraska (Leary site).

This phase seems to be slightly earlier than the subsequent Orr phase found on the lower portion of the Upper Iowa River as reported by M. Wedel, ${ }^{11}$ Bray $^{12}$ and Henning. ${ }^{13}$ Other Orr phase sites are found in the area of southeastern Minnesota, ${ }^{14}$ on the Iowa River in southeastern Iowa, ${ }^{15}$ in LaCrosse County, Wisconsin, ${ }^{16}$ four locations in northwestern Iowa $^{17}$ and possibly the Anker site in the Chicago, Illinois area. $^{18}$

The Bastian site in northwestern Iowa appears to be intermediate between the Correctionville-Blue Earth phase and the Orr phase and serves to link proto-historic Orr phase sites (nine of which have yielded European trade items) with the earlier phase in a long developmental sequence extending back to A.D. $950 .^{19}$

Additional Oneota materials have been recovered from south central Iowa along the Des Moines River by David Gradwohl while conducting salvage operations in the Red Rock and Saylorville Reservoirs. These materials are sufficiently different to be placed in a separate phase (Moingona) but relationships are poorly understood and dating has been inconclusive. ${ }^{20}$

The proto-historic and early historic Ioways probably lived a semi-sedentary life in much the same manner as their

${ }^{11} \mathrm{M}$. Wedel, op. cit., pp. 1-181.

${ }^{12}$ Robert T. Bray, "The Flynn Cemetery, An Orr Focus Oneota Burial Site in Alamakee County," Journal of the Iowa Archaelogical Society, (Iowa City, 1961), Vol. 10, Part 1, pp. 15-25.

${ }^{13}$ Henning, op. cit., pp. 1-180.

${ }^{14}$ Lloyd A. Wilford, "A Tentative Classification of the Prehistoric Cultures of Minnesota," American Antiquity, (Menasha, 1941), Vol. 6, No. 3, pp. 234-35.

${ }^{15}$ Henning, op. cit., p. 149.

${ }^{16}$ Guy E. Gibbon, "The Midway Site-An Intrasite Analysis," Madison, University of Wisconsin, 1966), Unpublished Master's Thesis.

${ }^{17}$ Henning, op. cit., p. 150.

${ }^{18}$ Elane A. Blum and Allen Liss, "The Anker Site," in Chicago Area Archaeology, ed. by E. A. Bluhm (Urbana, University of Illinois Press, 1961), Illinois Archaeological Survey, Inc., Bulletin No. 3, pp. 89-137.

${ }^{19}$ Henning, op. cit., p. 153.

${ }^{20}$ David M. Gradwohl, personal communication, April, 1971. 
Oneota ancestors had for over 600 years. There is little question that fairly early, perhaps A.D. 1600, the Ioway came under increasingly stronger influences from two sources: first, Plains Indians bearing the horse complex; and second, European traders and trappers through which they received such items as glass beads, iron knives, copper and brass beads and bracelets and axes. This influence probably took place through intermediaries at first, followed by direct contact soon after. AIAOUA TO IOWAY (1676-1836)

After the Aiaoua Indians made their first appearance in 1676 in Green Bay, they received periodic mention in various far flung sources until, ultimately, they left the state of Iowa, ceding their lands in favor of life along the Missouri. The first concrete information about the Ioway [Ayoes] was collected in 1685 by Nicolas Perrot, recorded by la Potherie and translated by Emma Blair. The following is an account of Perrot's visit to an Ioway village:

At their arrival the women fled; some gained the hills, and others rushed into the woods which extended along the river, weeping and raising their hands toward the sun. Twenty prominent men presented the calumet to Perrot, and carried him upon a buffalo-skin into the cabin of the chief, who walked at the head of this procession. When they had taken their places on the mat, this chief began to weep over Perrot's head, bathing it with his tears, and with moisture that dripped from his mouth and nose; and those who carried the guest did the same to him. These tears ended, the calumet was again presented to him; and the chief caused a great earthen pot, which was filled with tongues of buffaloes, to be placed over the fire. These were taken out as soon as they began to boil, and were cut into small pieces, of which the chief took one and placed it in his guest's mouth; Perrot tried to take one for himself, but the chief refused until he had given it to him, for it is their custom to place the morsels in the guest's mouth, when he is a captain, until the third time, before they offer the dish. He could not forbear spitting out this morsel, which was still all bloody (those same tongues were cooked that night in an iron pot); immediately some men, in great surprise, took their calumet, and perfumed them with tobacco smoke. Never in the world were seen greater weepers than those peoples; their approach is accompanied with tears and their adieu is the same. They have a very artless manner, also broad chests and deep voices. They are extremely courageous and good hearted. They often kill cattle and deer while running after them. They are howlers; they eat meat raw, or only warm it over a fire. 
They are never satiated for when they have any food they eat night and dav; but when they have none they fast very tranquilly. They are very hospitable, and are never more delighted than when they are entertaining strangers. ${ }^{21}$

This encounter was probably along the Upper Iowa River (Map 3, No. 1), according to Mott, and it could have been at the mouth of the Upper Iowa as plotted on the rather confusing Guillaume Delisle map. ${ }^{22}$ There may have been Ioway villages in several locations across the state of Iowa that were occupied contemporaneously at various times. Mott generally tries to trace the movement of a single group as reflected in numerous early accounts. She does discuss the possibility of more than one village on occasion. ${ }^{23}$ It seems likely that the scattered and often conflicting accounts of the Ioway during this period are at times referring to different groups of the increasingly mobile tribe.

The locations of ten Historic Ioway villages are plotted on Map 3. These locations are generalized areas for the most part, based on sketchy and incomplete documentation. The map was constructed primarily on the basis of information presented by Mott. ${ }^{24}$ Many of Mott's references were not available to the present study but they are very important and are presented in Appendix A.

The general discussion which follows traces the Ioways from 1676 to 1820 when they began a period of compulsory land cessions by which they gave up lands in Missouri, Minnesota and Iowa and began settling to the south and west along the Little Platte River in northwestern Missouri.

The first record of the Ioways after Perrot's visit to a village on the Upper Iowa (?) River in 1685 came from the Iowa Great Lakes region (Map 3, No. 2). Pierre LeSueur established a fort to the north at the confluence of the Blue Earth and Minnesota Rivers where he spent the winter of 1700-1701. Although his journal was lost, others (Bernard de

${ }^{21}$ Emma Blair, Indian Tribes of the Upper Mississippi Valley and Region of the Great Lakes (Cleveland, Arthur H. Clark Co., 1911), pp. 367-69.

${ }^{22}$ Mott, op. cit., p. $240 \& 307$.

${ }^{23}$ Ibid., pp. 246-47, p. $251 \& 256$.

${ }^{24}$ Ibid., pp. 234-258. 


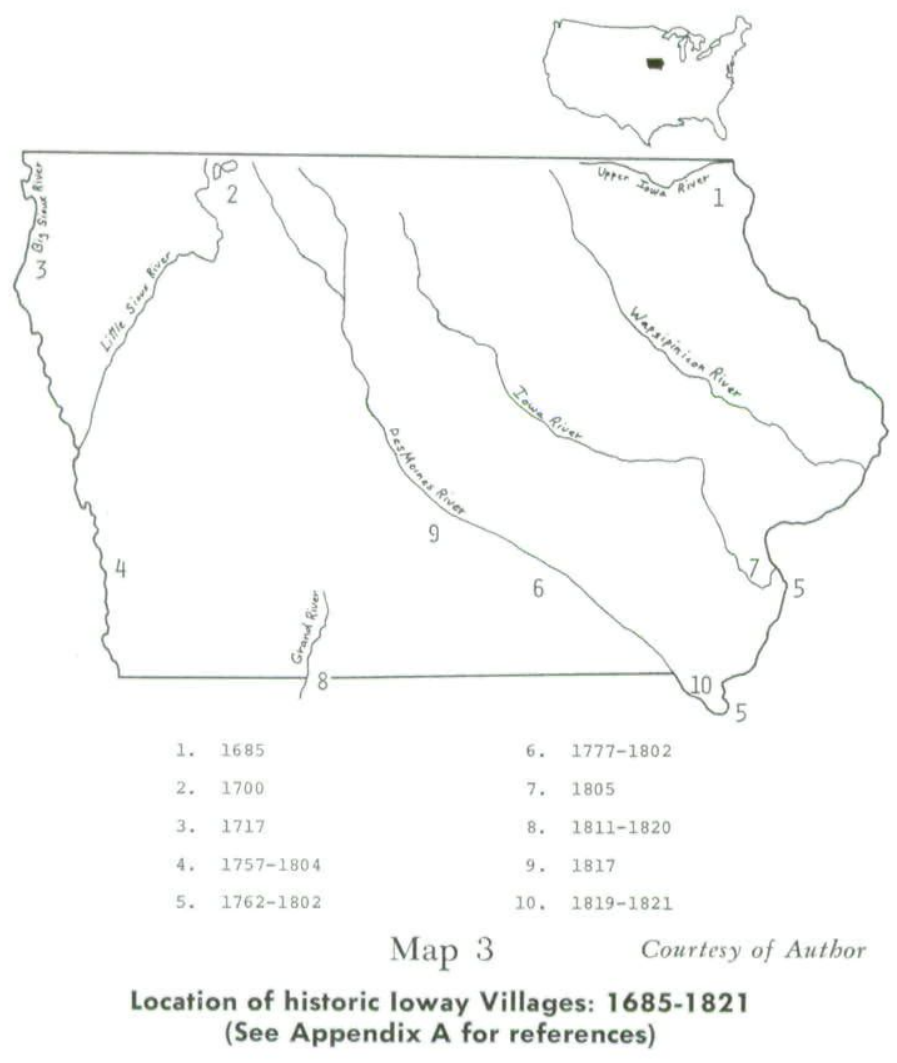

La Harpe and M. le Chevalier de Blaurain) had already incorporated it into their writings. Visiting Sioux reportedly told LeSueur that the area was periodically occupied by the Ioways (among others), and that they had a village on the shore of a lake thirty leagues to the west (see Appendix A for references). In addition, the Delisle maps of 1702 and 1703 show an Ioway village on the shore of a lake in this region. By the time LeSueur sent two men to establish contact with the lake group, however, they had already moved southwest to establish themselves on the Missouri-Big Sioux River area (Map 3, No. 3).

The Missouri-Big Sioux location was noted on two early maps (Vermale 1717 and Delisle 1718). In time it appears that 
the Ioway moved south and established a village near the present location of Council Bluffs, Iowa, (Map 3, No. 4) where they were recorded by various early travelers such as Lewis and Clark and H. M. Brackenridge. ${ }^{25}$ Actually there may have been more than one village at this time. Mott speculates that the Ioway might have obtained the horse while on the Missouri and feels that this might account for their mobility as indicated by reports from eastern Iowa during and after this time. ${ }^{26}$

Whatever the case, the Ioway are next recorded on the Mississippi River in Illinois in 1762 by Lieutenant James Gorrell, and in 1764 St. Ange, a commandant at Fort Chartres on the Mississippi just above the mouth of the Kaskaskia River, complained of Ioways bothering the French at Peoria. ${ }^{27}$ Actually there were two villages. The "Upper Ioway" village was located south of the confluence of the Iowa River and the "Lower Ioway" village was opposite the confluence of the Des Moines River and the Mississippi (Map 3, No. 5).

By 1777, Francisco Cruzat, in a letter to Don Bernando de Galvez, dated November 15, 1777, reported that the Iowas were eighty leagues from St. Louis near the present town of Selma, Iowa on the Des Moines River (Map 3, No. 6). This placement is supported by the age of Ioway chief Watchemonne, who at the age of approximately fifty had his portrait painted by C. B. King for McKenney and Hall's illustrated history. Watchemonne was said ${ }^{28}$ to have been born on the Des Moines River [probably around 1788]. This area must have been occupied by Ioways for some time.

A trader named Thomas G. Anderson spent the winter of 1801-1802 with the Ioway. He reported their position as being fifty miles up the Des Moines. The site is located in the immediate vicinity where whites established the town of Iowaville in 1837. The town was abandoned late in the Nineteenth

${ }^{25}$ Ibid., p. 248.

${ }^{26}$ Ibid., p. 249.

${ }^{27}$ Ibid., p. 251.

${ }^{28}$ Thomas L. MeKinney and James Hall, Biographical Sketches and Anecdotes of Ninety-five of 120 Principal Chiefs from the Indian Tribes of North America (Philadelphia, T. K. and P. G. Colling, Printers, 1938), p. 17. 
Century. ${ }^{29}$ Numerous other traders and government officials verify the general Iowaville location including Cutter in 1812, William Clark in 1816, Edward Tanner and Stephen Long in 1817, George Silby in 1820 and Jedidiah Morse in 1820, according to Mott. ${ }^{30}$

The Ioway may, at least in part, have remained along the Des Moines beyond the year 1820, but as early as 1805 Zebulon M. Pike reported an Ioway village on the Mississippi in what Mott argues to be the Iowa River area. Following John Todd she places the site about ten miles above the confluence of the Iowa and Mississippi Rivers ${ }^{31}$ (Map 3, No, 7 ).

Furthermore, there seems to have been Ioway groups settled on the Grand River at this same time according to William Clark, Governor of Missouri Territory. This report was verified by George Silby (letter to Thomas McKenney, 1820) when he remarked that the Ioway were divided to the point where he could not say how many villages they had or where they were. It appears that the Grand River village could have been in present day Iowa or Missouri (Map 3, No. 8).

There are indications that a portion of the Ioway moved up the Des Moines by 1817 to a location southeast of the present city of Des Moines. This is based on separate reports by Stephen Long and Edward Tanner. Although both reports are based on second hand information, they do coincide (Map 3, No. 9).

The last record of the Ioway (aside from the relocation of the "Pouting Party" who camped with the Pottawattamie in the 1840s) was in the year 1821. Thomas Forsyth reported their presence just below Keokuk, Iowa (Map 3, No. 10), and said that they had planted corn near Fort Edwards. In 1821 he asked for a subagency to deal with them. ${ }^{32}$

Three years later the Ioways signed a treaty with the United States Government (August 4, 1824) whereby they ceded all claims to land in Missouri. For this they were to receive $\$ 500$ per year for ten years in cash or merchandise.

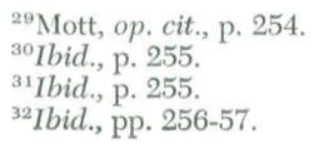


They were promised farm implements, cattle, and some assistance in their agricultural pursuits. ${ }^{33}$ On August 19, 1825 the Ioway entered into another treaty at Prairie du Chien. At this time they jointly claimed the right to peacefully occupy lands in Iowa until a division of claims could be made with the Sac and Fox. ${ }^{34}$

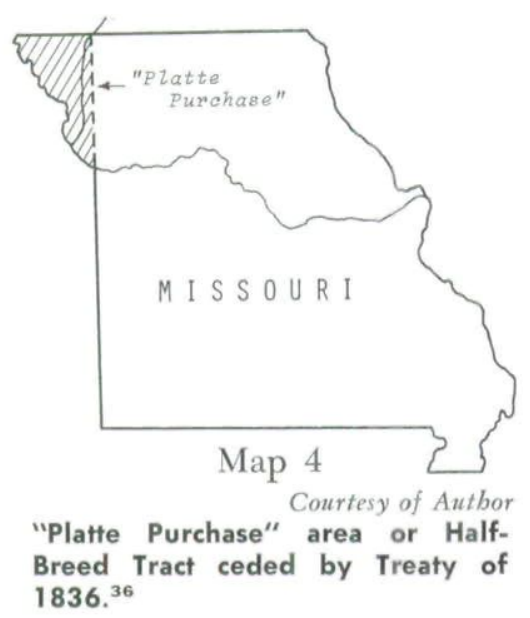

By a subsequent treaty at Prairie du Chien on July 15,1830 the Ioway ceded their joint claims to the United States government, although an article stipulated that the area between the state of Missouri and the Missouri River could be used by them, along with others the President might locate there. ${ }^{35}$ At that time this triangular shaped piece of land was not part of the state of Missouri, as the western boundary of the state was a north-south line leaving the Little Platte River valley and adjacent areas open to Indian claim (Map 4).

This tract of land was attractive to early settlers and the Missouri state legislature requested on February 24, 1835 that the lands be purchased by Congress. The Senate and House approved the resolution almost unanimously even though the decision contradicted the earlier treaty of 1830. In 1836 Congress appropriated $\$ 2,000$ for use in extinguishing Indian title in the area which has come to be known as the "Platte Purchase." General William Clark, Superintendent of Indian Affairs at St. Louis, negotiated with the Ioways and

${ }^{33}$ Charles J. Kappler, Indian Affairs: Laws and Treaties (Washington, 1904), Vol. 2, pp. 208-09.

${ }^{34}$ Ibid., pp. $250-51$.

${ }^{35}$ Ibid., p. 306.

${ }^{36}$ Ibid., p. 306. 
the Sac and Fox. ${ }^{37}$ This resulted in the Treaty of September 17, 1836 by which the three tribes ceded their land east of the Missouri River. This brought about a close to the second chapter of Ioway ethnohistory and marked the onset of reservation life.

During the period of 1676-1836 the Ioways roamed freely over Iowa, extending occasionally into parts of Minnesota, Illinois, Missouri and perhaps Wisconsin. At first notice the "Aiaoua" were probably little changed from their Oneota ancestors. Prehistoric village remains attributed to the Orr phase Oneota do not differ with material culture from early Historic sites except in the presence of trade items. It is not possible to say when the horse, tipi and other Plains traits were acquired.

Waldo R. Wedel states that Indians of western Kansas probably got the horse as early as 1640 and within 100 years it reached the Blackfoot of Alberta. ${ }^{38}$ Further, by 1800 practically all Plains tribes were mounted. It seems likely that the Ioway obtained the horse and perhaps other plains characteristics while they were in western Iowa prior to 1750 .

Agriculture was apparently never abandoned; it is reported by LeSueur in $1700^{39}$ and again in 1819 by Thomas Forsyth. ${ }^{40}$ They probably occupied their villages for a few years at a time and based their hunting activities from them. Hunting parties may account for sporadic hints of the Ioway making appearances some distance from their known villages. Mott, for example, mentions possible penetration to the Wapsipinicon River in 1728 and the murder of a Frenchman on the Des Moines River in $1755 .^{41}$

There is little reference to disease during this period but one might imagine that the Ioway were not exempt from a number of European introduced diseases which reached epidemic proportions among other better known tribes. Maximi-

${ }^{37}$ 23rd Cong., 2d Sess., Sen. Doc. 137 (Serial 268), p. 1; 24th Cong., 2d Sess., Sen. Doc. 1 (Serial 297 ), pp. 395-96.

${ }^{38}$ Waldo R. Wedel, Prehistoric Man on the Great Plains (Norman, University of Oklahoma Press, 1961), p. 290.

${ }^{39}$ Mott, op. cit., p. 224.

${ }^{40}$ Ibid., p. 256.

${ }^{41}$ Ibid., pp. 249-50. 
lian, in his travels (1832-34), did note that there were few vigorous men among the Omaha, Oto and Ioway and that the individuals he saw were much marked with smallpox. ${ }^{42}$ It is not possible to determine the actual effect of disease on the Ioway, but it was probably on the increase as reservation life was imposed upon the Ioway and other tribes.

Finally, the legendary battle of 1821 with the Sac and Fox may have had a significant impact on the Ioway. The battle (massacre?) is supposed to have been led by Black Hawk and was reportedly a factor in the migration of the Ioway to Missouri Territory. Mott doubts that a battle ever took place. ${ }^{43}$ Marshall McKusick, on the other hand, cites a rare book by A. R. Fulton (1888), entitled The Red Men of Iowa, as evidence for the massacre which is described in fair detail. ${ }^{44}$ Since the question seemed to rest on Fulton's sources of information, McKusick was contacted and reported that an early [and somewhat disreputable] trader in the settlement of Iowaville named J. H. Jordan supplied Fulton with information about the battle. Jordan, however, did not witness the conflict. ${ }^{45}$

Subsequently, Dean Straffin has taken an interest in the problem and believes that the Ioway village and the site of Iowaville are one in the same. ${ }^{46}$ No detailed report of artifacts recovered is available and no excavations have been undertaken. Finally, it should be noted that Don G. Spears and other members of the Southeast Chapter, Iowa Archaeological Society, who have studied the records, believe the elusive Ioway site may be three miles upstream from the site of the Iowaville settlement in an area adjacent to the place of Black Hawk's original grave. ${ }^{47}$

${ }^{42}$ Maximilian, Prince of Wied-Neuwied, "Travels in the Interior of North America: May 17, 1832-August 8, 1834," in Early Western Travels, ed. by R. G. Thwaites (Cleveland, A. H. Clark Co., 1843), Vol. 22, pp. 271-74.

${ }^{43}$ Mott, op. cit., p. 258.

${ }^{44}$ Marshall B. McKusick, Men of Ancient Iowa (Ames, Iowa State University Press, 1964), pp. 202-03.

${ }^{45}$ Marshall B. McKusick, personal communication, February, 1972.

${ }^{46}$ Dean F. Straffin, "Iowaville: A Possible Historic Ioway Site on the Lower Des Moines River," Proceedings of the Iowa Academy of Science, (Ames, 1972), Vol. 79, No. 1, pp. 44-46.

${ }^{47}$ Don G. Spears, personal communication, August, 1972. 
The problem of the legendary battle remains. Perhaps excavation and further archival research will eventually result in positively identifying the location of the site in question, and provide evidence pertaining to the "massacre."

APPENDIX A

References to the locations of Historic Iowa village sites (1676-1820) shown on Map 3 as reported by Mott (1938).

Map

Location

No.

Dates References

$1 \quad 1685$ Mott (1938: 240)

21700 Mott (1938: 242) cites Beaurain's Voyage de Le Sueur chez les Sioux in Margry's Decouvertes et Etablissement des Francis dans l'Ouest et dans le Sud de l'Amérique Septentrionale, Vol. VI, p. 78.

31717 Mott (1938: 247-249) cites Delisle's 1718 map "Map of Louisiana and the Course of the Mississippi" and Vermali's map "General Map of Louisiana" 1717.

1757- Mott (1938: 247-49) cites Mott in Annals of Iowa. 1804 Vol. 13, p. 170 (1922). Thwaites's Original Journals of the Lewis and Clark Expedition Vol. VI, p. 42. Brackenridge's Journal of a Voyage up the River Missouri in Thwaites's Early Western Travels, Vol. 6, p. 165.

1762- Mott (1938: 250-52) cites Lieutenant James Gor1777 rell's Journal in the Wisconsin Historical Collections, Vol. 1, p. 32. St. Ange's Report in the Wisconsin Historical Collections, Vol. 10, p. 293. Brion de la Tour's "Map of the United States of America and the Course of the Mississippi” 1784.

6 1777- Mott (1938: 253) cites Cruzart's Letter in Houck's 1802 The Spanish Regime in Missouri, Vol. 1, p. 145. Thomas G. Anderson's Narrative in the Wisconsin Historical Collections, Vol. 9, p. 151.

1805 Mott (1938: 255) cites Pike's An Account of a Voyage up the Mississippi River, p. 5. Todd's Early Settlement and Growth of Western Iowa, p. 184.

8 1811- Mott (1938: 256) cites William Clark's A Report of 1820 the Names and Probable Number of the Tribes of Indians in the Missouri Territory, dated November 4, 1816 in the Retired Classified Files, Indian Archives, Washington, D. C. George Silby's Letter in Morse's A Report to the Secretary of War of the United States, on Indian Affairs, p. 204.

Mott (1938: 257) cites Edward Tanner's Report in the Wisconsin Historical Collections, Vol. 8, p. 288. Stephen Long's Voyage in a Six-oared Skiff to the Falls of St. Anthony, in the Minnesota Historical Collections, Vol. 2, p. 81 . Mott (1938: 256-57) cites Thomas Forsyth's Jour1821 nal, 1819. 
Copyright of Annals of Iowa is the property of State of Iowa, by \& through the State Historical Society of Iowa and its content may not be copied or emailed to multiple sites or posted to a listserv without the copyright holder's express written permission. However, users may print, download, or email articles for individual use. 